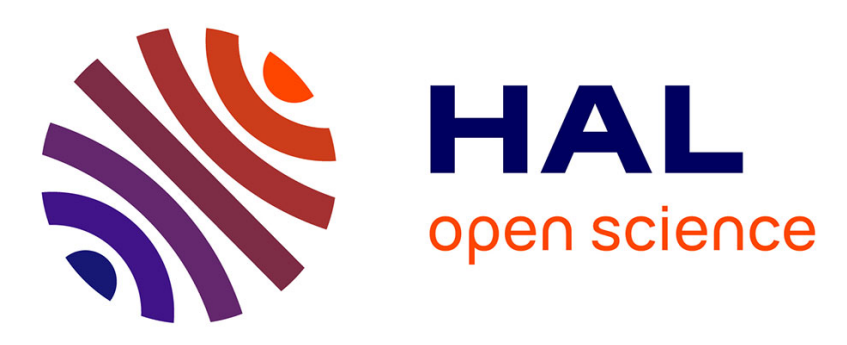

\title{
Nanoscale Hydration in Layered Manganese Oxides
}

Wei Cheng, Jerry Lindholm, Michael Holmboe, N Tan Luong, Andrey

Shchukarev, Eugene S Ilton, Khalil Hanna, Jean-François Boily

\section{To cite this version:}

Wei Cheng, Jerry Lindholm, Michael Holmboe, N Tan Luong, Andrey Shchukarev, et al.. Nanoscale Hydration in Layered Manganese Oxides. Langmuir, 2021, 37 (2), pp.666-674. 10.1021/acs.langmuir.0c02592 . hal-03128535

\section{HAL Id: hal-03128535 \\ https://hal.science/hal-03128535}

Submitted on 22 Feb 2021

HAL is a multi-disciplinary open access archive for the deposit and dissemination of scientific research documents, whether they are published or not. The documents may come from teaching and research institutions in France or abroad, or from public or private research centers.
L'archive ouverte pluridisciplinaire HAL, est destinée au dépôt et à la diffusion de documents scientifiques de niveau recherche, publiés ou non, émanant des établissements d'enseignement et de recherche français ou étrangers, des laboratoires publics ou privés.

\section{(c)(1)}

Distributed under a Creative Commons Attribution| 4.0 International License 


\title{
Nanoscale Hydration in Layered Manganese Oxides
}

\author{
Wei Cheng, Jerry Lindholm, Michael Holmboe, N. Tan Luong, Andrey Shchukarev, Eugene S. Ilton, \\ Khalil Hanna, and Jean-François Boily*
}

Cite This: Langmuir 2021, 37, 666-674

Read Online

ACCESS | W W Metrics \& More | 国 Article Recommendations | st Supporting Information

ABSTRACT: Birnessite is a layered $\mathrm{MnO}_{2}$ mineral capable of intercalating nanometric water films in its bulk. With its variable distributions of $\mathrm{Mn}$ oxidation states $\left(\mathrm{Mn}^{\mathrm{IV}}, \mathrm{Mn}^{\mathrm{III}}\right.$, and $\mathrm{Mn}^{\mathrm{II}}$ ), cationic vacancies, and interlayer cationic populations, birnessite plays key roles in catalysis, energy storage solutions, and environmental (geo)chemistry. We here report the molecular controls driving the nanoscale intercalation of water in potassium-exchanged birnessite nanoparticles. From microgravimetry, vibrational spectroscopy, and X-ray diffraction, we find that birnessite intercalates no more than one monolayer of water per interlayer when exposed to water vapor at $25{ }^{\circ} \mathrm{C}$, even near the dew point. Molecular dynamics showed that a single monolayer is an energetically favorable hydration state that consists of 1.33 water molecules per unit cell. This monolayer is stabilized by concerted potassium-water and direct water-birnessite interactions, and involves negligible waterwater interactions. Using our composite adsorption-condensation-intercalation model, we predicted humidity-dependent water loadings in terms of water intercalated in the internal

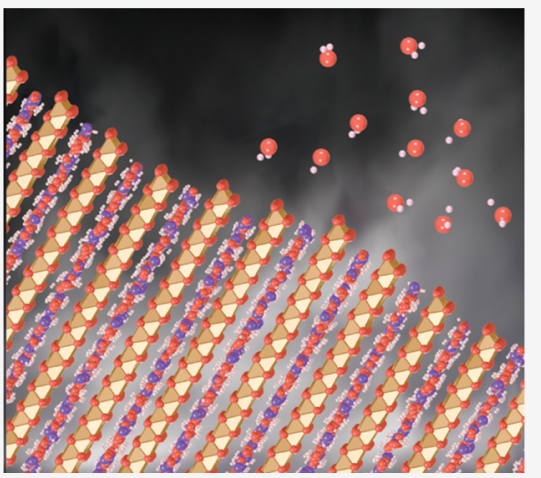
and adsorbed at external basal faces, the proportions of which vary with particle size. The model also accounts for additional populations condensed on and between particles. By describing the nanoscale hydration of birnessite, our work secures a path for understanding the water-driven catalytic chemistry that this important layered manganese oxide mineral can host in natural and technological settings.

\section{INTRODUCTION}

Birnessite $\left(\mathrm{MnO}_{2}\right)$ is a layered manganese oxide (Figure 1) occurring as fine-grained poorly crystalline nanoparticles or coatings in soils, sediments, and ferromanganese deposits. ${ }^{1-3}$ This phyllomanganate has the notable quality of accommodating nanometric water films within its structure. These films contribute to birnessite stability ${ }^{4,5}$ and host important solvent-
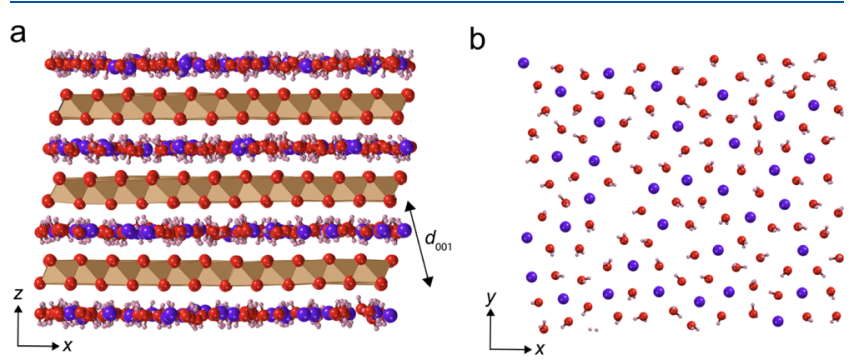

Figure 1. (a) Side view of the birnessite structure with an idealized 1layer $(1 \mathrm{~W})$ interlayer hydration state of $1.33 \mathrm{H}_{2} \mathrm{O}$ (red/pink) per unit cell. Sheets of Mn octahedra (brown/beige) are connected through edge-sharing basal oxygens (red). Charge imbalance caused by $\mathrm{Mn}^{\mathrm{III}}$ and $\mathrm{Mn}^{\mathrm{II}}$ is compensated by interlayer countercations (purple) and/or vacancies (not shown). (b) Basal face view of a single water layer, also partially hydrating interlayer countercations, in this case, $\mathrm{K}^{+}$. These images were generated by a snapshot of a molecular dynamics simulations and then edited for illustration purposes. driven processes, including ionic exchange and electron transfer reactions. Understanding the behavior of this hydration environment is essential for applications as varied as contaminant transport and redox geochemistry, ${ }^{6-9}$ catalysis, ${ }^{10,11}$ energy storage solutions, ${ }^{12}$ and even potentially harvesting atmospheric water in arid areas. ${ }^{13}$ Examples of knowledge required for these various applications include molecular configurations ${ }^{14}$ of intercalated water layers and of their thermal stabilities ${ }^{4,15}$

The $\mathrm{MnO}_{2}$ structure of birnessite is formally composed of stacked sheets of edge-sharing $\mathrm{MnO}_{6}$ octahedra (Figure $1)^{16-18}$ and forms ultrathin nanoplatelets with a surface dominated with its basal face. ${ }^{19,20}$ It has a formal average oxidation state (AOS) of 4.0, but synthetic and natural forms commonly contain a mixture of $\mathrm{Mn}$ oxidation states $\left(\mathrm{Mn}^{\mathrm{IV}}\right.$, $\mathrm{Mn}^{\mathrm{III}}$, and $\left.\mathrm{Mn}^{\mathrm{II}}\right) \cdot{ }^{21-24}$ In nature, birnessite or vernadite with AOS values as low as $\sim 3.5$ is probably more common because natural organic matter has a strong propensity to reduce $\mathrm{Mn}^{\mathrm{IV}} \cdot{ }^{21,25-28}$ Cationic vacancies represent an additional source of charge imbalance with, for example, previously reported

Received: September 1, 2020

Revised: December 11, 2020

Published: January 6, 2021 
populations of $12 \%$ in birnessite prepared in acidic and $6 \%$ in alkaline media. ${ }^{21,29,30}$ Countercations (e.g., $\mathrm{Na}^{+}, \mathrm{K}^{+}$, and $\mathrm{Mn}^{2+}$ ) in the interlayer region counterbalance the missing charges resulting from the mixed Mn-oxidation states and vacancies. These can collectively alter the structure and the chemical reactivity of intercalated water. For example, manganese oxides with well-defined crystallographic sites host structured water layers, while those of lower crystallinity host relatively more disordered water. ${ }^{31}$ Understanding the forms of water trapped in the interlayer region when birnessite is exposed to moist air is especially central for understanding how they mediate reactions of natural and technological importance. Of note, resolving this chemistry can also be challenged by the coexistence of water condensed in pores between particles.

Building upon our recent work on water vapor binding on minerals, ${ }^{32-38}$ we here resolved the humidity-dependent loadings of water achieved on birnessite nanoparticles, alongside their resulting vibrational spectral profiles and the interlayer expansion they generate. We predict the microscopic hydration states of birnessite using a composite adsorptioncondensation-intercalation model that we recently developed for layered minerals. Our model accounts for water intercalated in the internal and external basal faces of birnessite (Figure 1). ${ }^{38}$ We also provide additional insight into the structure and dynamics of the intercalated water by molecular dynamics simulations of a representative form of birnessite. This work should facilitate future studies following the solvent-driven chemistry of this important nanolayered manganese oxide when exposed to moist air. ${ }^{39,40}$

\section{MATERIALS AND METHODS}

2.1. Synthesis and Experimental Characterization. The birnessite samples used in this work are important analogues to the most common vernadite and biogenic Mn oxides in nature and thus especially informative to understand natural and technological processes. ${ }^{21,25,41,42}$ To this end, we prepared birnessite formed in acidic (AcidBir) and alkaline $\left(\delta-\mathrm{MnO}_{2}\right)$ solutions, which are two synthetic representative isomorphs of layered $\mathrm{MnO}_{2}$ with a hexagonal structure. ${ }^{25}$ Here, we follow the classification of Villalobos et al., ${ }^{25}$ where AcidBir is synthesized by reduction ${ }^{16}$ of a permanganate solution under acidic conditions, and $\delta-\mathrm{MnO}_{2}$ is synthesized from a redox reaction of permanganate with $\mathrm{Mn}^{2+}$ under alkaline conditions.

AcidBir was prepared by the dropwise addition of $166 \mathrm{~mL}$ of $12 \mathrm{M}$ $\mathrm{HCl}$ to a vigorously stirred $2.5 \mathrm{~L}$ solution of $0.4 \mathrm{M} \mathrm{KMnO}_{4}$ kept in a water bath at $90{ }^{\circ} \mathrm{C} .{ }^{16}$ The resulting solution was reacted for an additional $10 \mathrm{~min}$ after completion of the titration. The precipitate was then washed with ultrapure water by repeated cycles of centrifugation/decantation until the conductivity was close to $0 \mu \mathrm{S} /$ $\mathrm{cm} . \delta-\mathrm{MnO}_{2}$ was, in contrast, prepared by adding an $80 \mathrm{~mL}$ solution of $0.1 \mathrm{M} \mathrm{KMnO}_{4}$ and a $160 \mathrm{~mL}$ solution of $0.1 \mathrm{M} \mathrm{KOH}$ to $1640 \mathrm{~mL}$ of ultrapure water at $25{ }^{\circ} \mathrm{C}$. An aliquot of $120 \mathrm{~mL}$ of a $0.1 \mathrm{M} \mathrm{MnCl}_{2}$ solution was thereafter added dropwise to this solution under vigorous stirring. All synthesis procedures were carried out in polypropylene bottles, and all washed precipitates were stored as aqueous suspensions in polyethylene bottles at $4{ }^{\circ} \mathrm{C}$ for a 2 month period prior the onset of this work.

A portion of the precipitates was oven-dried at $60{ }^{\circ} \mathrm{C}$ for particle characterization, a detailed account of which is in the Supplementary Section. Crystalline $\mathrm{MnO}_{2}$ phase purity was confirmed by X-ray diffraction (XRD; PANalytical X'Pert Pro X-ray diffractometer; Figure S1). B.E.T. ${ }^{25}$ specific surface areas of $59.2 \mathrm{~m}^{2} / \mathrm{g}$ for AcidBir and 204 $\mathrm{m}^{2} / \mathrm{g}$ for $\delta$ - $\mathrm{MnO}_{2}$ were obtained from 90-point adsorption/ desorption $\mathrm{N}_{2}(\mathrm{~g})$ isotherms (Micromeritics). The surface Mn:O:K compositions of 1.00:1.49:0.20 for AcidBir, " $\mathrm{MnO}_{2}(0.20 \mathrm{~K})$ ", and 1.00:1.38:0.17 for $\delta-\mathrm{MnO}_{2}, " \mathrm{MnO}_{2}(0.17 \mathrm{~K})$ ", were resolved by X-ray photoelectron spectroscopy (XPS; Kratos Axis Ultra DLD electron spectrometer; see the text in the Supporting Information and Figures $\mathrm{S} 2-\mathrm{S} 4)$. The $\mathrm{O} / \mathrm{Mn}$ ratios were lower than the stoichiometrically expected value of 2 , and could result from (i) the near surface composition of birnessite surfaces probed by XPS (i.e., within the first $\sim 10 \mathrm{~nm}$ of the topmost region), and (ii) the loss of chemisorbed water to vacuum.

Surface Mn AOS values of AcidBir (AOS = 3.69; 72\% $\mathrm{Mn}^{\mathrm{IV}}$, 25\% $\mathrm{Mn}^{\mathrm{III}}$, and $3 \% \mathrm{Mn}^{\mathrm{II}}$ ) and $\delta-\mathrm{MnO}_{2}\left(\mathrm{AOS}=3.52 ; 58 \% \mathrm{Mn}^{\mathrm{IV}}, 36 \%\right.$ $\mathrm{Mn}^{\mathrm{III}}$, and $6 \% \mathrm{Mn}^{\mathrm{II}}$ ) were resolved by fitting of the $\mathrm{Mn} 3 \mathrm{~s}$ region according to the method of Ilton et al. ${ }^{43}$ Of note, these oxidation states are highly similar to those of Ling et al. ${ }^{44}$ obtained using the same analysis method of a birnessite synthesized by reduction of permanganate under acidic conditions ( $\mathrm{AOS}=3.69 ; 68 \% \mathrm{Mn}^{\mathrm{IV}}, 22 \%$ $\mathrm{Mn}^{\mathrm{III}}$, and $\left.4 \% \mathrm{Mn}^{\mathrm{II}}\right)$, as in AcidBir, and for another birnessite by a redox reaction at high $\mathrm{pH}\left(\mathrm{AOS}=3.69 ; 60 \% \mathrm{Mn}^{\mathrm{IV}}, 38 \% \mathrm{Mn}^{\mathrm{III}}, 2 \%\right.$ $\left.\mathrm{Mn}^{\mathrm{II}}\right)$, as in $\delta-\mathrm{MnO}_{2}$. See the supplementary section for a discussion on the fitting procedure and results, in Figures S2-S4 and Table S1.

2.2. Water Vapor Uptake. Binding of water vapor on birnessite during dynamic vapor sorption (DVS) ${ }^{45}$ was monitored by (1) microgravimetry, (2) Fourier transform infraRed (FTIR) spectroscopy, and (3) basal spacing $\left(d_{001}\right)$ obtained by powder XRD.

2.2.1. Microgravimetry. Microgravimetric measurements of water vapor uptake by birnessite were obtained using a DVS Advantage ET 2 instrument (Surface Measurement Systems). A 21-point isotherm cycle occurred between 0 and $98 \%$ relative humidity $(\mathrm{RH})$ at $25{ }^{\circ} \mathrm{C}$, and we used $\sim 30 \mathrm{mg}$ samples initially dried at $110^{\circ} \mathrm{C}$ for $3 \mathrm{~h}$. The equilibrium criterion for each stepwise increase in $\% \mathrm{RH}$ was set to a change in mass of less than 0.001 wt $\%$ per minute. A complete adsorption-desorption isotherm cycle took up to $\sim 3$ days (Figure S5).

2.2.2. Adsorption-Condensation-Intercalation Modeling. Water loadings $\left(w_{\text {tot }}\right)$ obtained by microgravimetry were predicted using our composite adsorption-condensation-intercalation model, ${ }^{38}$ which was implemented in a MATLAB R2019b (The Mathworks, Inc.) code. The model accounts for coexisting water populations (i) on the external basal faces (adsorption; $w_{\text {ads }}$ ), (ii) condensed between particle (condensation; $w_{\text {cond }}$ ) water, and (ii) on the internal basal face (intercalation; $w_{\text {int }}$ ), such that

$$
w_{\text {tot }}=w_{\text {ads }}+w_{\text {cond }}+w_{\text {int }}
$$

These populations were expressed in terms of the number of $\mathrm{H}_{2} \mathrm{O}$ bound per unit cell (UC). We note that a single UC consists of two $\mathrm{MnO}_{2}$ units. Additionally, the conversion of the experimentally obtained "mass of bound $\mathrm{H}_{2} \mathrm{O}$ per mass of $\mathrm{MnO}_{2}$ " to " $\mathrm{H}_{2} \mathrm{O} / \mathrm{UC}$ " is made using the molar masses $\left(m_{\mathrm{MnO}_{2}}\right)$ of $\mathrm{MnO}_{2}(0.20 \mathrm{~K})$ for AcidBir and of $\mathrm{MnO}_{2}(0.17 \mathrm{~K})$ for $\delta-\mathrm{MnO}_{2}$.

In this work, one complete monolayer $(1 \mathrm{~W})$ on the basal face of birnessite corresponds to $W_{1, \text { int }}=1.33 \mathrm{H}_{2} \mathrm{O} / \mathrm{UC}$ or $\rho_{\text {Wads }}=9 \mathrm{H}_{2} \mathrm{O} /$ $\mathrm{nm}^{2}$, which are values determined by our molecular dynamics simulations to be presented in the latter part of this paper. We determined the total populations associated to the external basal faces in terms of $\mathrm{H}_{2} \mathrm{O} / \mathrm{UC}$ with

$$
W_{1, \mathrm{ads}}=\rho_{W_{\mathrm{ads}}} \cdot s_{\mathrm{s}} \cdot 2 m_{\mathrm{MnO}_{2}}
$$

where $s_{\mathrm{s}}$ is the total B.E.T. specific surface area. Incidentally, we do not explicitly account for water populations at particle edges, which represent a low proportion of the particle surface area.

Predictions of internal water loadings $\left(w_{\text {int }}\right)$ achieved by intercalation were treated using Dubinin-Asthakhov theory ${ }^{46}$ with

$$
w_{\text {int }}=W_{1, \text { int }} \cdot e^{-(-A / E)^{i}}
$$

Here, the binding strength of water (E) and the pore size distribution (e.g., $i=2$ for Gaussian) are adjustable parameters. These two adjustable parameters account for the humidity-dependence shape of the water uptake curve. ${ }^{47}$ The water vapor pressure dependence on binding in eq 3 is expressed through the adsorption potential $(A)$

$$
A=R T \ln \frac{p}{p_{0}}
$$


where $p$ is the partial pressure of water vapor and $p_{\mathrm{o}}$ is the saturation (dew point) pressure. As the results from XRD will show, a maximum of only one water layer $(1 \mathrm{~W})$ is accommodated in each interlayer region of birnessite.

Predictions of water binding on the external surface were made with a theory first developed by Do and Do, ${ }^{48}$ but here adapted for minerals to account for coexisting adhesive adsorption $\left(w_{\text {ads }}\right)$ and cohesive water-water condensation $\left(w_{\text {cond }}\right)$ interactions, respectively, with

$$
w_{\mathrm{ads}}=W_{1, \mathrm{ads}} \frac{K_{\mathrm{f}} \sum_{1}^{n=\beta+1} n^{*} p / p_{0}^{n}}{1+K_{\mathrm{f}} \sum_{1}^{n=\beta+1} p / p_{0}^{n}}
$$

and

$$
w_{\text {cond }}=C_{\mu \mathrm{s}} \frac{K_{\mu} \sum_{1}^{n=\alpha+1} p / p_{0}^{n}}{K_{\mu} \sum_{1}^{n=\alpha+1} p / p_{0}^{n}+\sum_{1}^{n=\alpha+1} p / p_{0}^{n-\alpha}}
$$

The adsorption term (eq 5) makes use of a fixed total binding density of $W_{1, \text { ads }}$ (eq 2), a fixed bond order $(\beta=0)$, and an adjustable binding constant $\left(K_{\mathrm{f}}\right)$. The condensation term (eq 6) involves the condensable water density $\left(C_{\mu \mathrm{s}}\right)$, the condensation constant $\left(K_{\mu}\right)$, and the critical number of water molecules in a nanocluster needed to trigger condensation.

2.2.3. Vibrational Spectroscopy. Water vapor binding to birnessite was also monitored by FTIR spectroscopy. All FTIR spectra were collected with a Bruker Vertex 70/V FTIR spectrometer, equipped with a DLaTGS detector. The spectra were collected in the 600-4000 $\mathrm{cm}^{-1}$ range at a resolution of $4.0 \mathrm{~cm}^{-1}$ and at a forward/reverse scanning rate of $10 \mathrm{kHz}$. Each spectrum was an average of 500 scans.

Centrifuged wet pastes of birnessite were deposited on a diamond window of an attenuated total reflectance (ATR) cell (Golden Gate, single-bounce). They were dried with a heat gun to $\sim 110^{\circ} \mathrm{C}$, then to a hot stream of dry $\mathrm{N}_{2}(\mathrm{~g})$, and then covered with a lid enabling the passage of a flow of $250 \mathrm{~mL} / \mathrm{min}_{2}(\mathrm{~g})$ over the sample set to $25^{\circ} \mathrm{C}$. FTIR spectra were collected during the drying period to monitor the loss of water until the intensities of the $\mathrm{O}-\mathrm{H}$ stretching and bending bands became constant. Accordingly, exposure of our sample to $0.4 \%$ $\mathrm{RH}$, our driest $\mathrm{N}_{2}(\mathrm{~g})$ gas at $25 \pm 1{ }^{\circ} \mathrm{C}$, revealed residual levels of intercalated water (Figure S6). See the Supplementary Section for additional experiments providing information on the conditions necessary for fully removing these most recalcitrant water molecules from birnessite (Figure S7).

Water vapor adsorption and desorption experiments were carried out by exposing the resulting mineral film to $0.4-95 \% \mathrm{RH}$ in the reaction cell at $25 \pm 1{ }^{\circ} \mathrm{C}$. A $250 \mathrm{~mL} / \mathrm{min}$ flow of water vapor of controlled pressure was first generated by mixing predetermined proportions of humid $\mathrm{N}_{2}(\mathrm{~g})$ and dry $\mathrm{N}_{2}(\mathrm{~g})$ using a humidity generator module (proUmid MHG32). Water vapor pressures were continuously monitored by a sensor equipped with the module and a nondispersible infraRed device (LI-7000, Licor Inc). A separate deuteration exchange experiment (Figure S6), in which birnessite was suspended in $\mathrm{D}_{2} \mathrm{O}(1)$ for 3 days, showed that the intercalated water populations were all responsive to changes in chemical gradient.

Spectra sets from each DVS experiments were analyzed using the multivariate curve resolution-alternating least square (MCR-ALS) method. ${ }^{49}$ Absorbance data, represented in the matrix format $A_{m \times n}$ of $m$ wavenumbers and $n$ water vapor pressures, were decomposed into their MCR spectral components $(\varepsilon)$, and their respective concentration profiles $(C)$, according to the Beer-Lambert law $(A=\varepsilon \cdot C)$. A singular value decomposition of matrix $A_{m \times n}$ was used to estimate the dimensionality of spectral components required to reproduce a given variance of the data. All calculations were performed in the computational environment of MATLAB R2019b (The Mathworks, Inc.).

2.2.4. $d_{001}$ Spacing by $X$-ray Diffraction. Interlayer expansion and collapse, respectively, resulting from the intercalation and withdrawal of water, were monitored by powder X-ray diffraction (XRD). AcidBir and $\delta-\mathrm{MnO}_{2}$ powders were first heated to $105^{\circ} \mathrm{C}$ for $3 \mathrm{~h}$ under a dry $\mathrm{N}_{2}$ (g) flow to remove all interlayer water. This was confirmed by the resulting XRD-derived $d$-spacing. After cooling to $25{ }^{\circ} \mathrm{C}$ under the same dry $\mathrm{N}_{2}(\mathrm{~g})$ flow, humidity was then incrementally increased to 98\% during an adsorption leg and then incrementally decreased during the desorption leg. The samples were allowed to equilibrate at each preselected $\mathrm{RH}$ value for $30 \mathrm{~min}$ prior to collecting the diffractograms. The data were acquired using a PANalytical X'Pert ${ }^{3}$ Powder instrument ( $1.54187 \AA \mathrm{CuK} \bar{\alpha}$ beam at $45 \mathrm{kV}$ and $40 \mathrm{~mA})$ at a resolution of $0.0334^{\circ}$ in the $2-50^{\circ} 2 \theta$ range.

Due to the low signal-to-noise ratio obtained in the transmission mode, humidity-dependent $d_{001}$ values were determined with Bragg's law after fitting a Gaussian function of the background-corrected 001 reflection. These analyses produced $d_{001}$ data for AcidBir only. Diffractograms of the considerably smaller $\delta-\mathrm{MnO}_{2}$ particles were of insufficient quality to extract reliable $d_{001}$ values, and are therefore not reported.

2.2.5. Molecular Dynamics. To gain direct molecular-scale insight into the hydration of birnessite, molecular dynamics (MD) simulations of $\mathrm{K}^{+}$-saturated birnessite at different water loadings were also undertaken. The lattice of one $\mathrm{UC}^{14}$ was expanded into a system containing $6 \times 12 \times 4 \mathrm{UCs}$, with a composition of $\mathrm{K}_{144}\left[\mathrm{Mn}_{576} \mathrm{O}_{1152}\right] \times\left(\mathrm{H}_{2} \mathrm{O}\right)_{3840}$. This initial composition corresponded to an average of $0.25 \mathrm{~K}^{+}$ions and 13.333 water molecules per UC. After energy minimization and $2 \mathrm{~ns}$ of volume and pressure optimization, $61 \times 3 \mathrm{~ns}$ successive production runs in the isobaricisothermal ensemble (NPT) were performed at decreasing water loadings. This was realized by successively evaporating a constant number of randomly selected water molecules $(0.22$ water molecules per UC per step) from each interlayer region, while preserving the same $d_{001}$ of each interlayer at each step. Each evaporation step was followed by a 100 ps of pre-equilibration run not included in the analysis.

All simulations were carried out using GROMACS ${ }^{50}$ with a 1 fs time step and a $1.0 \mathrm{~nm}$ cutoff for the direct van der Waals and for Coulombic interactions. Long-range Coulombic interactions were accounted for by the particle-mesh Ewald (PME) method. For practical reasons, the birnessite lattice was modeled with $\mathrm{Mn}^{3.75+}$ as in Cygan et al. ${ }^{39}$ but with Lennard-Jones forcefield parameters recently reported by Newton and Kwon. ${ }^{51}$ Water was described with the SPC/ $\mathrm{E}$ model, ${ }^{52}$ and $\mathrm{K}^{+}$ions were described with SPC/E compatible ionpair potentials from Joung and Cheatham. ${ }^{53}$

MD simulation results were analyzed for $d_{001}$ along the UC $c$ axis, hydrogen bonding, $\mathrm{K}^{+}-\mathrm{O}$ coordination, and $\mathrm{K}^{+}$and water diffusion coefficients. The energetics of stable hydration states were analyzed with $^{54,55}$

$$
Q(N)=U(N)-U\left(N^{\mathrm{o}}\right)-U_{\text {bulk }}\left(N-N^{\mathrm{o}}\right)
$$

$Q(N)$ is the hydration immersion energy $(\mathrm{J} / \mathrm{g})$ relative to a reference hydration state $N^{\circ}, N$ is the number of water molecules per birnessite unit cell $\left(\mathrm{H}_{2} \mathrm{O} / \mathrm{UC}\right), U$ is the time-averaged potential energy, and $U_{\text {bulk }}(46.8 \mathrm{~kJ} / \mathrm{mol})$ is the mean interaction energy of a bulk SPC/E water molecule. In a second set of simulations, we replaced $\mathrm{K}^{+}$by $\mathrm{Na}^{+}$ to compare with the MD results of Newton and $\mathrm{Kwon}^{51}$ (Figure S8).

\section{RESULTS AND DISCUSSION}

3.1. Water Intercalation Causes Interlayer Expansion. The humidity-dependent water loadings on AcidBir and $\delta$ $\mathrm{MnO}_{2}$ are characteristic of a Type II adsorption/desorption isotherm, ${ }^{56}$ with some hysteresis in the desorption leg. The isotherms became nearly congruent when expressed on a mass per mass $\left(\mathrm{mg} \mathrm{H}_{2} \mathrm{O} / \mathrm{g}\right.$ birnessite $)$ or unit cell $\left(\mathrm{H}_{2} \mathrm{O} / \mathrm{UC}\right)$ basis (Figure 2) and reached $\sim 1.5-1.6 \mathrm{H}_{2} \mathrm{O} / \mathrm{UC}$ just below the dew point of water. This congruency for both materials indicates that the majority of bound water was associated to the birnessite bulk.

XRD-derived $d_{001}$ spacing values of AcidBir (Figure 3) revealed a sharp increase in $d_{001}$, from $0.690 \mathrm{~nm}$ at $5 \% \mathrm{RH}$, where the interlayer region is chiefly dehydrated $(0 \mathrm{~W})$, to $0.735 \mathrm{~nm}$ at $98 \% \mathrm{RH}$. As the 001 diffraction peak intensity 


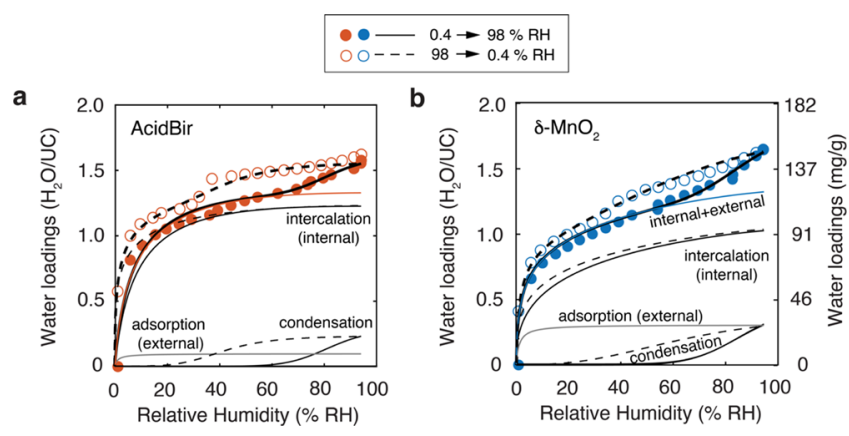

Figure 2. Gravimetrically derived water loadings on (a) AcidBir (59.2 $\mathrm{m}^{2} / \mathrm{g}$ ) and (b) $\delta-\mathrm{MnO}_{2}\left(204 \mathrm{~m}^{2} / \mathrm{g}\right)$, collected as adsorption (closed symbols) and desorption (open symbols) isotherms at $25{ }^{\circ} \mathrm{C}$. Loadings are shown in terms of bound water molecules per unit cell $\left(\mathrm{H}_{2} \mathrm{O} / \mathrm{UC}\right)$ and birnessite mass-normalized (left ordinate axis) mass of $\mathrm{H}_{2} \mathrm{O}(\mathrm{mg} / \mathrm{g})$. Lines (see labels) are predictions of water binding during the adsorption (full) and desorption (dashed) leg of the data collection and generated using the composition adsorptioncondensation-intercalation model of this study. The orange line in (a) and the blue line in (b) show the sum of internally and externally bound water to the basal faces of birnessite.
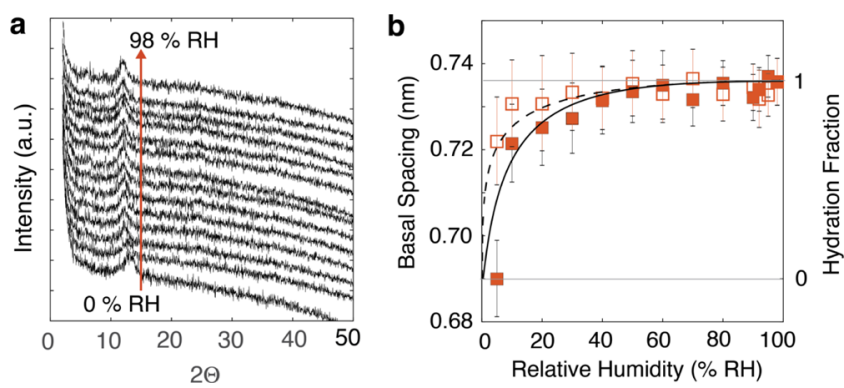

Figure 3. (a) Transmission-mode XRD diffractograms of AcidBir exposed to $0-98 \% \mathrm{RH}$ and (b) result of $d_{001}$ basal spacing (left ordinate axis) analyses from these data (filled square = adsorption; open square $=$ desorption), also showing uncertainties. The model predictions of $d_{001}$ in (b) (full line for adsorption; dashed for desorption) were taken from the Dubinin-Asthakhov theory ${ }^{46}$ term derived from the microgravimetric water binding data (Figure 2a). This model prediction of the hydration fraction (right ordinate axis) was scaled such that $d_{001}=0.690 \mathrm{~nm}$ at $0 \mathrm{~W}\left(0 \mathrm{H}_{2} \mathrm{O} / \mathrm{UC}\right)$ and $d_{001}=$ $0.735 \mathrm{~nm}$ at $1 \mathrm{~W}\left(1.33 \mathrm{H}_{2} \mathrm{O} / \mathrm{UC}\right)$. Diffractograms for $\delta-\mathrm{MnO}_{2}$ were of insufficient quality to be shown here, due to the small particle size.

remained relatively unchanged, no significant change in the stacking of $\mathrm{MnO}_{2}$ sheets is likely to have been induced by humidity. The interlayer expansion of $0.045 \mathrm{~nm}$ corresponds to the intercalation of no more than a single monolayer $(1 \mathrm{~W})$, as will be confirmed further by the simulations of the last section of this paper. These results also revealed a population of intercalated water resilient to outgassing below $\sim 40 \% \mathrm{RH}$. The population responsible for the microgravimetrically measured hysteresis above this value must therefore arise from the surface and interparticle water as the $d_{001}$ spacing values are fully reversible at these higher levels of humidity.

Using a maximal water population of $1.33 \mathrm{H}_{2} \mathrm{O} / \mathrm{UC}$ (e.g., $121 \mathrm{mg}$ of $\mathrm{H}_{2} \mathrm{O}$ per $\mathrm{g} \mathrm{MnO}_{2}(0.17 \mathrm{~K})$ for $\left.\delta-\mathrm{MnO}_{2}\right)$ on the internal and external basal faces of birnessite, we modeled the microgravimetric data of Figure 2 with our adsorptioncondensation-intercalation model (Table 1). The model accounts for constant proportions of internally and externally bound water on AcidBir and $\delta-\mathrm{MnO}_{2}$, and this assumption is justified by the constant intensities of the 001 diffraction peaks of Figure 3. The model involves a single set of values to predict adsorption on external basal faces, as well as highly comparable values for the intercalation term, except for differing pore size distributions (parameter $i$ in eq 3 ) in AcidBir and $\delta$ - $\mathrm{MnO}_{2}$. We must consider that the sum of the intercalation (internal) and adsorption (external) terms (orange line in Figure 2a and blue line in Figure 2b) represents the total amount of water associated to the basal faces of birnessite, regardless of whether the dry particles are stacked in such a way that a portion of the particle surface area $\left(s_{s}\right.$, determined by B.E.T.) is no longer accessible for direct adsorption in the water vapor binding experiments. We make this statement because our estimate of external site densities from B.E.T. values may be too high for $\delta$ $\mathrm{MnO}_{2}$, and this could explain the lowered contributions of the intercalation term. It does not, however, explain the different pore size distributions, which are obtained even by removing the adsorption term from the model. Still, the intercalation term of our model reproduces the humidity dependence of the experimentally derived $d_{001}$ values of AcidBir, when scaled as described in Figure $3 \mathrm{~b}$. Additionally, the model explains the greater portion of the hysteresis of the microgravimetric data in terms of liquid water populations between particles, which we find by vibrational spectroscopy in the following section. Our model provides, as such, an insightful depiction of the distribution of water on and within birnessite particles exposed to moist air and almost up to the dew point of water.

3.2. Vibrational Spectral Profile of Intercalated Water. The vibrational spectroscopic response of bound water was monitored in thin birnessite films exposed to water vapor (Figure 4). First, we note that the $\mathrm{O}-\mathrm{H}$ stretching $\left(\nu_{1}\right)$ region (Figure $4 \mathrm{a}, \mathrm{d}$ ) responds to water uptake through the development of (i) a $3230 \mathrm{~cm}^{-1}$ band from $\mathrm{O}-\mathrm{H}$ stretches with strong intermolecular coupling and from the Fermi resonance $\left(2 \cdot \nu_{2}\right)$ of the bending mode $\left(\nu_{2} \approx 1630 \mathrm{~cm}^{-1}\right)$, (ii) a $3400 \mathrm{~cm}^{-1}$ band from water involved in a hydrogen bonding network with other water molecules, and (iii) a $\sim 3562 \mathrm{~cm}^{-1}$ band from water molecules that are directly hydrogen-bonded with oxygens of the basal faces of the interlayer region. This latter assignment is supported by our previous work on layered aluminosilicates, as by our molecular simulations to be presented in the following section. ${ }^{57}$ The water bending $\left(\nu_{1}\right)$

Table 1. Adsorption-Condensation-Intercalation Modeling Parameters of the Microgravimetric Data

\begin{tabular}{|c|c|c|c|c|c|c|c|c|c|c|}
\hline \multirow[b]{2}{*}{ sample } & \multirow[b]{2}{*}{ experiment } & \multicolumn{3}{|c|}{ adsorption $^{a}$} & \multicolumn{3}{|c|}{ condensation $^{b}$} & \multicolumn{3}{|c|}{ intercalation $^{c}$} \\
\hline & & $W_{1, \mathrm{ads}}{ }^{d}$ & $\log _{10} K_{f}$ & $\beta$ & $C_{\mu s}{ }^{d}$ & $\log _{10} K_{\mu}$ & $\alpha$ & $W_{1, \text { int }}^{d}$ & $\log _{10} E$ & $i$ \\
\hline$\delta-\mathrm{MnO}_{2}$ & $0 \rightarrow 98 \% \mathrm{RH}$ & 0.30 & 1.90 & 0 & 0.46 & 0.48 & 8.4 & 1.33 & 3.90 & 1.2 \\
\hline$\delta-\mathrm{MnO}_{2}$ & $98 \rightarrow 0 \% \mathrm{RH}$ & 0.30 & 1.90 & 0 & 0.40 & 0.48 & 2.9 & 1.33 & 3.98 & 1.2 \\
\hline AcidBir & $0 \rightarrow 98 \% \mathrm{RH}$ & 0.09 & 1.90 & 0 & 0.32 & 0.61 & 8.5 & 1.33 & 3.91 & 2.0 \\
\hline AcidBir & $98 \rightarrow 0 \% \mathrm{RH}$ & 0.09 & 1.90 & 0 & 0.22 & 0.55 & 4.2 & 1.33 & 4.08 & 2.0 \\
\hline
\end{tabular}

${ }^{a}$ Equation 5. ${ }^{b}$ Equation 6. ${ }^{c}$ Equation 3. ${ }^{d} \mathrm{H}_{2} \mathrm{O} / \mathrm{UC}$. 

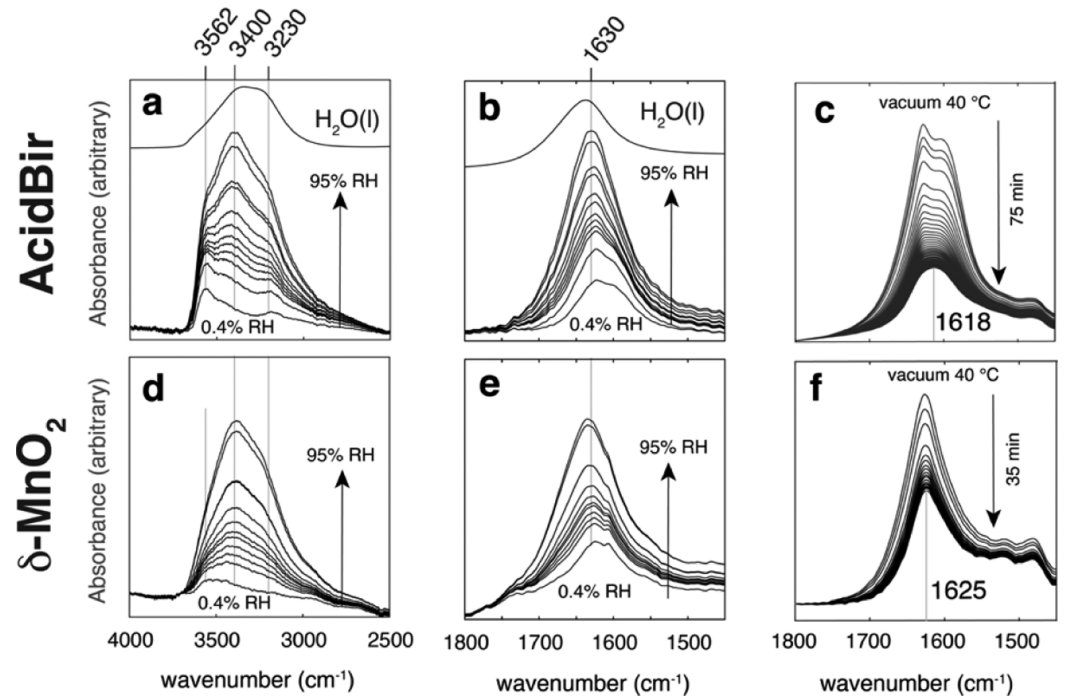

Figure 4. FTIR spectra of $(\mathrm{a}-\mathrm{c})$ AcidBir and $(\mathrm{d}-\mathrm{f}) \delta$ - $\mathrm{MnO}_{2}$. Samples were collected in ATR mode for experiments in the 0.4-95\% RH range (adsorption leg) at $25{ }^{\circ} \mathrm{C}(\mathrm{a}, \mathrm{b}, \mathrm{d}, \mathrm{e})$ and in transmission mode for samples exposed to vacuum at $40{ }^{\circ} \mathrm{C}(\mathrm{c}, \mathrm{f})$. Note that the intensities in $\mathrm{c}$ and $\mathrm{f}$ are lower than those at $0.4 \% \mathrm{RH}$, and represent very low hydration states.
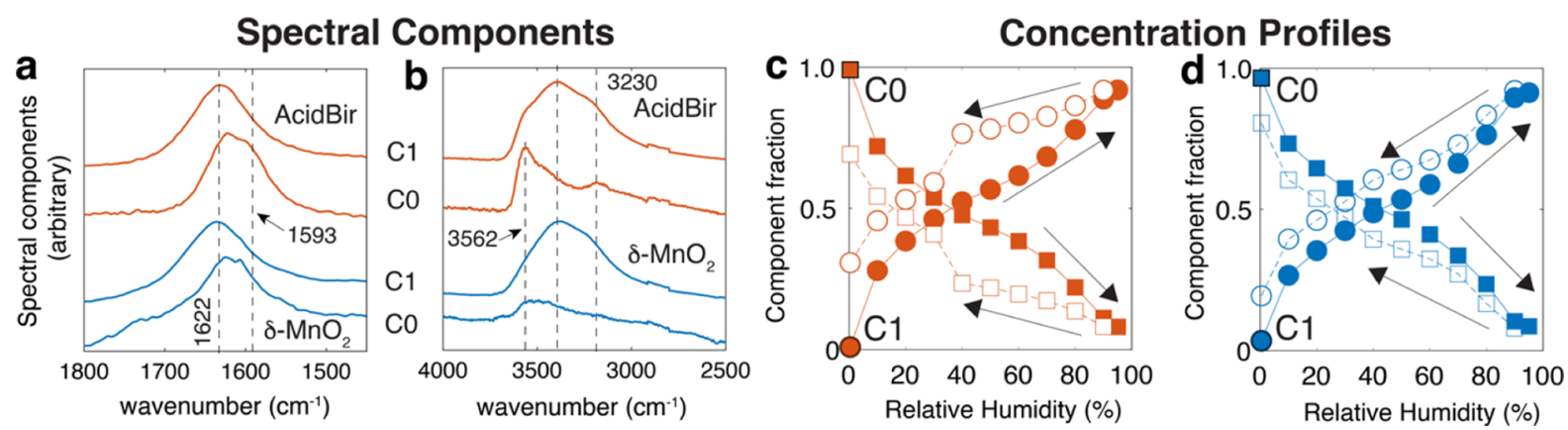

Figure 5. Chemometric analysis of FTIR spectra of AcidBir (orange) and $\delta$ - $\mathrm{MnO}_{2}$ (blue) from the adsorption (Figure 4a,b,d,e) and desorption (not shown) legs. The analysis decomposed the spectra into spectral components $(\mathrm{a}, \mathrm{b})$ and relative concentration profiles $(\mathrm{c}, \mathrm{d})$. Concentration profiles show both adsorption (filled) and desorption (open) legs.
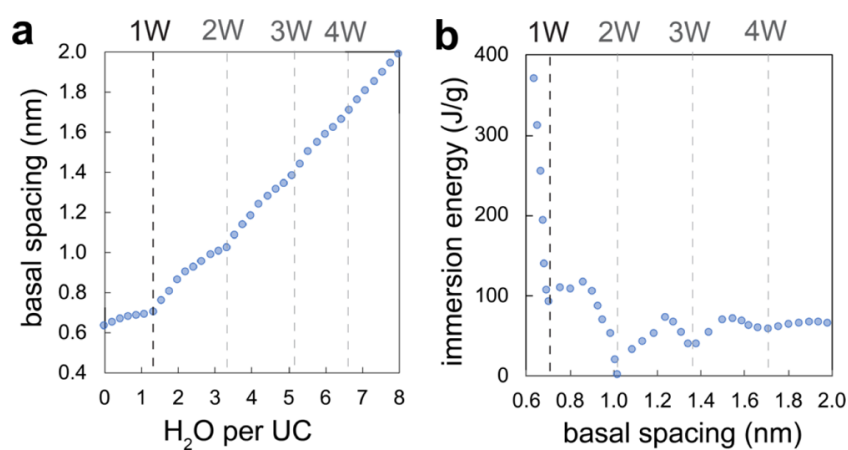

Figure 6. (a) Predicted $d_{001}$ (along the UC $c$ axis) as a function of water loading, here expressed as the water molecule per $\mathrm{UC}$ of $\mathrm{K}^{+}$birnessite. (b) Corresponding immersion energy profiles $v s d_{001}$. Here, $0.705 \mathrm{~nm}=1 \mathrm{~W}$ and $1.02 \mathrm{~nm}=2 \mathrm{~W}$. Note that the immersion energy curve indicates possible higher and quasi-stable hydration states at $1.36(3 \mathrm{~W})$ and $1.68(4 \mathrm{~W}) \mathrm{nm}$. See Figure S8 for comparison with Na-birnessite, which was also reported in the literature. ${ }^{30}$ Dashed vertical lines indicate the loci of hydration states.

region of intercalated water (Figure $4 \mathrm{~b}, \mathrm{e}$ ) also acquired a shape comparable to that of liquid water at high humidity at $\sim 1630 \mathrm{~cm}^{-1}$. Low humidity (e.g., $0.4 \% \mathrm{RH}$ ) and outgassing experiments (Figure 4c,f; S6), however, revealed residual water

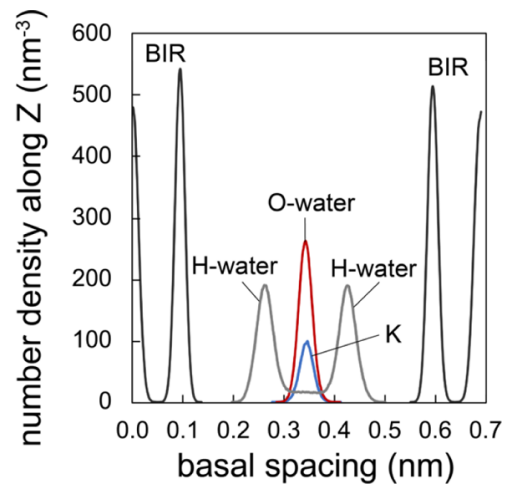

Figure 7. Density profile data binned over a single $6 \times 121 \mathrm{~W}$ birnessite layer with the composition $\mathrm{K}_{36}\left[\mathrm{Mn}_{144} \mathrm{O}_{288}\right] \times\left(\mathrm{H}_{2} \mathrm{O}\right)_{96}$, demonstrating the position of the $\mathrm{K}^{+}$counterions and water oxygens being fully centered in the interlayer region. This contrasts with water hydrogens, which are almost exclusively oriented toward the basal oxygens of the birnessite lattice.

populations of relatively blue-shifted bending frequencies that likely arise from potassium and perhaps vacancy-bound water molecules pointed out by Ling et al. ${ }^{44}$ For example, a doubleband for AcidBir during outgassing (Figure 4c) could be evidence for coexisting water populations under low water 

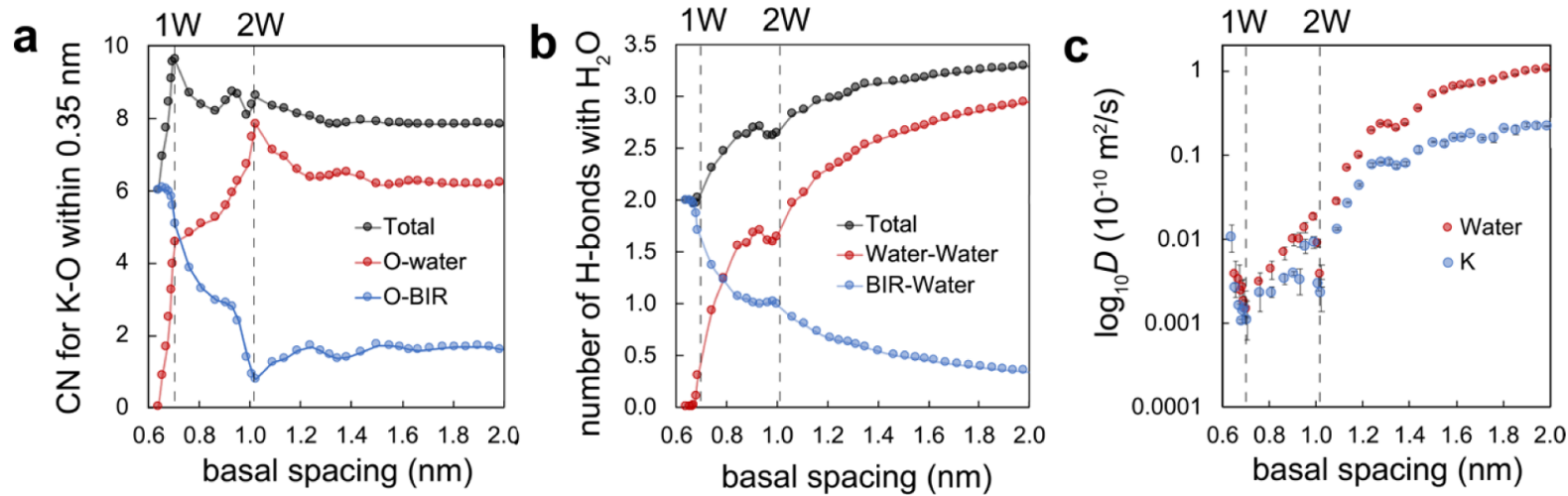

Figure 8. MD simulation results showing the basal spacing dependence $\left(d_{001}\right)$ on $(\mathrm{a})$ the coordination environment of $\mathrm{K}^{+}$, (b) hydrogen bond populations, and (c) diffusion coefficients of water. (a) First-shell coordination of $\mathrm{K}^{+}$to oxygens, belonging to either water ( $\mathrm{O}$-water, red) or birnessite (O-BIR, blue).The coordination numbers were calculated from the radial distribution functions up to the minima of the first coordination shell at $0.35 \mathrm{~nm}$ (Figure S9). (b) Number of hydrogen bonds between water and birnessite. (c) Diffusion coefficients of water (red) and $\mathrm{K}^{+}$(blue). Dashed vertical lines indicate ideal $1 \mathrm{~W}$ and $2 \mathrm{~W}$ hydration states.

loadings. We will, however, not focus on this aspect of hydration in this study.

The humidity dependence on interlayer water populations was resolved further by extracting spectral components (Figure $5 \mathrm{a}, \mathrm{b})$ and concentration profiles (Figure $5 \mathrm{c}, \mathrm{d}$ ) of the most dehydrated ( $\mathrm{C} 0)$ and hydrated ( $\mathrm{C} 1)$ forms of birnessite from the spectra of Figure $4 \mathrm{a}, \mathrm{b}, \mathrm{d}, \mathrm{e} .{ }^{49}$ These chemometric analyzes revealed that only two spectral components accounted for over $96 \%$ of the variance of the spectra over the $0-98 \% \mathrm{RH}$ range. Because additional components could not be extracted from these data, contributions from intercalated, adsorbed, and condensed interparticle water are implicitly overlapped in component $\mathrm{C} 1$. We ascribe the difficulties that arise in separating these contributions to the lack of variance in the spectra resulting from the concurrent binding of different water populations of highly comparable spectral profiles.

The resulting concentration profiles (Figure $5 \mathrm{c}, \mathrm{d}$ ) revealed systematic and reversible changes in the adsorption and removal of water. The steep change in $\mathrm{C} 1$ in the adsorption leg within the $0-10 \% \mathrm{RH}$ range correlates with the increase in $d_{001}$ values (Figure $3 \mathrm{~b}$ ). Changes at larger humidity relate, in contrast, to a combination of a smaller change intercalation and binding to the external basal face and of a more dominant contribution from the condensation regime. Finally, we note that the desorption leg reveals a stronger hysteresis for AcidBir than in $\delta-\mathrm{MnO}_{2}$ in the $30-90 \% \mathrm{RH}$ range. These results confirm that the hysteresis seen in the microgravimetric data (Figure 1) is from condensed interparticle water, as little hysteresis was observed in the $d_{001}$ spacing data.

3.3. Molecular Structure and Dynamics of Intercalated Water. To gain further insight into the molecular controls on the formation and stability of the intercalated water, we performed MD simulations on an idealized birnessite with intercalated $\mathrm{K}^{+}$ions (Figure 1). We also explored hydration states larger than $1 \mathrm{~W}$ to evaluate whether these could have been reached in the laboratory.

The dependence of $d_{001}$ with water loading and the corresponding immersion energy data, derived from these simulations, indicate a stable $1 \mathrm{~W}$ hydration state at $0.705 \mathrm{~nm}$ (Figure 6). This $d_{001}$ value is slighter below our experimentally derived value of $\sim 0.735 \mathrm{~nm}$. It corresponds to $1.33 \mathrm{H}_{2} \mathrm{O} / \mathrm{UC}$ $\left(5.33 \mathrm{H}_{2} \mathrm{O} / \mathrm{K}^{+}\right)$, which is the intercalation density chosen for modeling the microgravimetric data (Figure 2). Simulations also identified higher hydration states at $1.02 \mathrm{~nm}(2 \mathrm{~W}), 1.36$ $\mathrm{nm}(3 \mathrm{~W})$, and $1.68 \mathrm{~nm}(4 \mathrm{~W})$, but none of these $d_{001}$ values correspond to our experimental values, which strongly indicate that the highest hydration state that can be achieved by birnessite in moist air is $1 \mathrm{~W}$. This is consistent with previous accounts showing that the $2 \mathrm{~W}$ state, informally known as buserite, is only stable in liquid water. ${ }^{1,58,59}$

Our simulated stable $1 \mathrm{~W}$ hydration state was nearly monoclinic, with average UC dimensions of $a=0.511, b=$ 0.295 , and $c=0.705 \mathrm{~nm}$ and angles of $\alpha=90.0, \beta=104.0$, and $\gamma=89.8^{\circ}$. These results are in line with reported dimensions of $\mathrm{Na}$-birnessite by Newton and Kwon ${ }^{51}$ and are within $4 \%$ of the values of two previous studies. ${ }^{60,61} \mathrm{We}$ also find that $\mathrm{K}^{+}$and water oxygens were positioned in the center interlayer region (Figure 7), in between basal oxygens of the birnessite lattice. This symmetric interlayer structure deviates from previous simulation studies, ${ }^{39}$ possibly due to contrasting water contents and forcefield parameters. Still, our results show similar positions of $\mathrm{K}^{+}$and its coordinating water, as was previously shown with $\mathrm{MD}$ for Na-birnessite. ${ }^{39,51}$

Our simulations also revealed (i) the coordination number of interlayer $\mathrm{K}^{+}$, (ii) hydrogen bond populations, and (iii) the diffusion coefficients $(D)$ of $\mathrm{K}^{+}$and water in birnessite (Figure 8). In particular, the $1 \mathrm{~W}$ state displayed a local maximum in the number of $\mathrm{K}^{+}$-oxygen interactions (Figure $8 \mathrm{a}$ ), with $\sim 10$ $\mathrm{O}$ within $0.35 \mathrm{~nm}, \sim 5$ of which are $\mathrm{O}$-sites from the basal face and $\sim 5$ from water oxygen. It is a hydration state with the maximum number of donating hydrogen bonds $(2$ per $\mathrm{O})$ to birnessite basal oxygen groups (observed at $3562 \mathrm{~cm}^{-1}$ in Figure $5 b$ ) and the least number of water-water interactions (Figure $8 \mathrm{~b}$ ). This latter observation thus implies that the hydrogen-bonded water populations seen by vibrational spectroscopy must arise from condensed water between the particles, not from the interlayer region. Finally, our simulations also show that the $1 \mathrm{~W}$ state is also the one with the lowest diffusion coefficients for both $\mathrm{K}^{+}$and water and even the lowest of all simulated hydration states (Figure $8 \mathrm{c}$ ). For comparison, the diffusion coefficient of liquid water $(D=$ $\left.2.68 \times 10^{-9} \mathrm{~m}^{2} / \mathrm{s}\right)^{55}$ is four orders of magnitude larger than that of the $1 \mathrm{~W}$ state. These findings consequently underscore the singular attributes of water molecules intercalated in the interlayer region of birnessite. 


\section{CONCLUSIONS}

By combining evidence from microgravimetry, vibrational spectroscopy, X-ray diffraction, and adsorption modeling, we showed that birnessite exposed to water vapor accommodates no more than a single monolayer of water in its interlayer region at $25{ }^{\circ} \mathrm{C}$. The $2 \mathrm{~W}$ state of birnessite, known as buserite, is therefore not achieved by exposure of water vapor under ambient pressure and temperature. ${ }^{14,62,63}$

The $1 \mathrm{~W}$ hydration state of $\mathrm{K}^{+}$-intercalated birnessite contains 1.33 water molecules per unit cell. This population can be distributed in the internal and external basal faces of the nanoparticles, the proportions of which vary with particle size. Condensed water on and between particle surfaces appears at $\sim 50 \% \mathrm{RH}$ during adsorption but disappears below 20\% RH during desorption. The $1 \mathrm{~W}$ state expands the basal spacing to $d_{001}=0.735 \mathrm{~nm}$ and consists of a single layer of water molecules simultaneously hydrating interlayer $\mathrm{K}^{+}$and donating hydrogen bonds to O-sites on the basal face. Unlike liquid water, those in the $1 \mathrm{~W}$ state of birnessite form almost no intermolecular hydrogen bonds, and their diffusion coefficient is four orders of magnitude lower than that of liquid water. This explains the distinct solvation environment offered by water intercalated in the birnessite bulk. The combined macroscopic, structural, and molecular information gathered for this work should provide new opportunities for exploring catalytic reactions driven by birnessite that are of great importance to nature and technology.

\section{ASSOCIATED CONTENT}

\section{(s) Supporting Information}

The Supporting Information is available free of charge at https://pubs.acs.org/doi/10.1021/acs.langmuir.0c02592.

Reflection-mode XRD diffractograms; Mn 2p and Mn 3s XPS spectra; O(1s) spectrum; Mn 3s region; temperature-programmed desorption of water; evacuation of residual water from $\mathrm{d}-\mathrm{MnO} 2$ and AcidBir in vacuum; molecular dynamics simulations of water intercalation in birnessite; radial distribution functions; and X-ray photoelectron spectroscopy results (PDF)

\section{AUTHOR INFORMATION}

\section{Corresponding Author}

Jean-François Boily - Department of Chemistry, Umeå University, SE-901 87 Umeå, Sweden; ㅇorcid.org/00000003-4954-6461; Phone: +46 73833 2678; Email: jeanfrancois.boily@umu.se

\section{Authors}

Wei Cheng - University Rennes, École Nationale Supérieure de Chimie de Rennes, CNRS, UMR 6226, 35708 Rennes, France

Jerry Lindholm - Department of Chemistry, Umeå University, SE-901 87 Umeå, Sweden

Michael Holmboe - Department of Chemistry, Umeå University, SE-901 87 Umeå, Sweden; 이이.org/00000003-3927-6197

N. Tan Luong - Department of Chemistry, Umeå University, SE-901 87 Umeå, Sweden

Andrey Shchukarev - Department of Chemistry, Umeå University, SE-901 87 Umeå, Sweden
Eugene S. Ilton - Physical Sciences Division, Pacific Northwest National Laboratory, Richland, Washington 99352, United States; (1) orcid.org/0000-0003-4931-5217

Khalil Hanna - University Rennes, École Nationale Supérieure de Chimie de Rennes, CNRS, UMR 6226, 35708 Rennes, France; (1) orcid.org/0000-0002-6072-1294

Complete contact information is available at: https://pubs.acs.org/10.1021/acs.langmuir.0c02592

\section{Notes}

The authors declare no competing financial interest.

\section{ACKNOWLEDGMENTS}

This work was supported by the Swedish Research Council through a grant to J.-F.B. (2016-03808; 2020-04853) and to M.H. (2019-04733) and by the CNRS (PICS 2018-2020) through a grant to J.-F.B and K.H. W.C. was supported by the China Scholarship Council for a Ph.D. grant and by Rennes Métropole (France) for a mobility grant for an extended research visit at Umea University. K.H. is also supported by Institut Universitaire de France (IUF). E.S.I. was supported by the U.S. Department of Energy (DOE), Office of Science, Office of Basic Energy Sciences (BES), Chemical Sciences, Geosciences, and Biosciences Division through its Geosciences program at the Pacific Northwest National Laboratory (PNNL). Simulations were enabled by the Swedish National Infrastructure of Computing (SNIC) at the High Performance Computing Center North (HPC2N) (SNIC 2019/3-487).

\section{REFERENCES}

(1) Post, J. E. Manganese oxide minerals: Crystal structures and economic and environmental significance. Proc. Natl. Acad. Sci. 1999, 96, 3447-3454.

(2) Chukhrov, F. V.; Gorshkov, A. I.; Rudnitskaya, E. S.; Beresovskaya, V. V.; Sivtsov, A. V. Manganese Minerals in Clays: A Review. Clays Clay Miner. 1980, 28, 346-354.

(3) McKenzie, R. Manganese Oxides and Hydroxides. In Minerals in Soil Environments, 2 ed.; Dixon, J. B., Weed, S. B., Eds.; Soil Science Society of America: Madison, Wisconsin, USA, 1989; Vol. 1, pp 439465.

(4) Johnson, E. A.; Post, J. E. Water in the interlayer region of birnessite: Importance in cation exchange and structural stability. Am. Miner. 2006, 91, 609-618.

(5) Villalobos, M.; Carrillo-Cárdenas, M.; Gibson, R.; LópezSantiago, N. R.; Morales, J. A. The influence of particle size and structure on the sorption and oxidation behaviour of birnessite: II. Adsorption and oxidation of four polycyclic aromatic hydrocarbons. Environ. Chem. 2014, 11, 279-288.

(6) Fischel, M. H. H.; Fischel, J. S.; Lafferty, B. J.; Sparks, D. L. The influence of environmental conditions on kinetics of arsenite oxidation by manganese-oxides. Geochem. Trans. 2015, 16, 15.

(7) Eren, E.; Gumus, H.; Sarihan, A. Synthesis, structural characterization and $\mathrm{Pb}(\mathrm{II})$ adsorption behavior of $\mathrm{K}-$ and $\mathrm{H}$ birnessite samples. Desalination 2011, 279, 75-85.

(8) Villalobos, M.; Escobar-Quiroz, I. N.; Salazar-Camacho, C. The influence of particle size and structure on the sorption and oxidation behavior of birnessite: I. Adsorption of $\mathrm{As}(\mathrm{V})$ and oxidation of As(III). Geochim. Cosmochim. Acta 2014, 125, 564-581.

(9) Ling, F. T.; Post, J. E.; Heaney, P. J.; Ilton, E. S. The relationship between $\mathrm{Mn}$ oxidation state and structure in triclinic and hexagonal birnessites. Chem. Geol. 2018, 479, 216-227.

(10) Lucht, K. P.; Mendoza-Cortes, J. L. Birnessite: A Layered Manganese Oxide To Capture Sunlight for Water-Splitting Catalysis. J. Phys. Chem. C 2015, 119, 22838-22846. 
(11) Kang, Q.; Vernisse, L.; Remsing, R. C.; Thenuwara, A. C.; Shumlas, S. L.; McKendry, I. G.; Klein, M. L.; Borguet, E.; Zdilla, M. J.; Strongin, D. R. Effect of Interlayer Spacing on the Activity of Layered Manganese Oxide Bilayer Catalysts for the Oxygen Evolution Reaction. J. Am. Chem. Soc. 2017, 139, 1863-1870.

(12) Shan, X. Q.; Guo, F. H.; Charles, D. S.; Lebens-Higgins, Z.; Razek, S. A.; Wu, J. P.; Xu, W. Q.; Yang, W. L.; Page, K. L.; Neuefeind, J. C.; Feygenson, M.; Piper, L. F. J.; Teng, X. W. Structural water and disordered structure promote aqueous sodium-ion energy storage in sodium-birnessite. Nat. Commun. 2019, 10, 4975.

(13) Wang, J.; Dang, Y.; Meguerdichian, A. G.; Dissanayake, S.; Kankanam-Kapuge, T.; Bamonte, S.; Tobin, Z. M.; Achola, L. A.; Suib, S. L. Water Harvesting from the Atmosphere in Arid Areas with Manganese Dioxide. Environ. Sci. Technol. Lett. 2020, 7, 48-53.

(14) Post, J. E.; Heaney, P. J.; Cho, Y. Neutron diffraction study of hydrogen in birnessite structures. Am. Miner. 2011, 96, 534-540.

(15) Choi, H. S.; Kim, S. J.; Kim, J. J. Dehydration behaviors of interlayer water in systhetic Buserites. Geosci. J. 2004, 8, 273-279.

(16) McKenzie, R. M. The synthesis of birnessite, cryptomelane, and some other oxides and hydroxides of manganese. Mineral. Mag. 1971, 38, 493-502.

(17) Kang, L.; Zhang, M.; Liu, Z.-H.; Ooi, K. IR spectra of manganese oxides with either layered or tunnel structures. Spectrochim. Acta, Part A 2007, 67, 864-869.

(18) Drits, V. A.; Silvester, E.; Gorshkov, A. I.; Manceau, A. Structure of synthetic monoclinic Na-rich birnessite and hexagonal birnessite; I, Results from X-ray diffraction and selected-area electron diffraction. Am. Miner. 1997, 82, 946-961.

(19) Jolivet, J.-P.; Cassaignon, S.; Chanéac, C.; Chiche, D.; Durupthy, O.; Portehault, D. Design of metal oxide nanoparticles: Control of size, shape, crystalline structure and functionalization by aqueous chemistry. C. R. Chim. 2010, 13, 40-51.

(20) Liang, X.; Zhao, Z.; Zhu, M.; Liu, F.; Wang, L.; Yin, H.; Qiu, G.; Cao, F.; Liu, X.; Feng, X. Self-assembly of birnessite nanoflowers by staged three-dimensional oriented attachment. Environ. Sci.: Nano 2017, 4, 1656-1669.

(21) Villalobos, M.; Lanson, B.; Manceau, A.; Toner, B.; Sposito, G. Structural model for the biogenic $\mathrm{Mn}$ oxide produced by Pseudomonas putida. Am. Miner. 2006, 91, 489-502.

(22) McKenzie, R. M. Manganese oxides and hydroxides. In Minerals in Soil Environments; Dixon, J. B., Weed, S. B., Eds.; Madison Press: Wisconsin, 1989; pp 439-465.

(23) Post, J. E. Manganese oxide minerals: Crystal structures and economic and environmental significance. Proc. Natl. Acad. Sci. 1999, 96, 3447-3454.

(24) Birkner, N.; Navrotsky, A. Thermodynamics of manganese oxides: Sodium, potassium, and calcium birnessite and cryptomelane. Proc. Natl. Acad. Sci. 2017, 114, E1046-E1053.

(25) Villalobos, M.; Toner, B.; Bargar, J.; Sposito, G. Characterization of the manganese oxide produced by Pseudomonas putida strain MnB1. Geochim. Cosmochim. Acta 2003, 67, 2649-2662.

(26) Wang, Y.; Feng, X.; Villalobos, M.; Tan, W.; Liu, F. Sorption behavior of heavy metals on birnessite: Relationship with its $\mathrm{Mn}$ average oxidation state and implications for types of sorption sites. Chem. Geol. 2012, 292-293, 25-34.

(27) Sun, Q.; Cui, P.-X.; Fan, T.-T.; Wu, S.; Zhu, M.; Alves, M. E.; Zhou, D.-M.; Wang, Y.-J. Effects of $\mathrm{Fe}(\mathrm{II})$ on Cd(II) immobilization by $\mathrm{Mn}(\mathrm{III})$-rich $\delta$-MnO2. Chem. Eng. J. 2018, 353, 167-175.

(28) Wang, Q.; Yang, P.; Zhu, M. Structural Transformation of Birnessite by Fulvic Acid under Anoxic Conditions. Environ. Sci. Technol. 2018, 52, 1844-1853.

(29) Manceau, A.; Lanson, B.; Drits, V. A. Structure of heavy metal sorbed birnessite. Part III: Results from powder and polarized extended X-ray absorption fine structure spectroscopy. Geochim. Cosmochim. Acta 2002, 66, 2639-2663.

(30) Villalobos, M.; Bargar, J.; Sposito, G. Mechanisms of Pb(II) sorption on a biogenic manganese oxide. Environ. Sci. Technol. 2005, 39, 569-576.
(31) Potter, R. M.; Rossman, G. R. The tetravalent manganese oxides identification, hydration, and structural relationships by infrared spectroscopy. Am. Mineral. 1979, 64, 1199-1218.

(32) Boily, J.-F.; Yeşilbaş, M.; Md. Musleh Uddin, M.; Baiqing, L.; Trushkina, Y.; Salazar-Alvarez, G. Thin Water Films at Multifaceted Hematite Particle Surfaces. Langmuir 2015, 31, 13127-13137.

(33) Yeşilbaş, M.; Boily, JF Particle Size Controls on Water Adsorption and Condensation Regimes at Mineral Surfaces. Sci. Rep. 2016, 6, 32136.

(34) Song, X.; Boily, J.-F. Water vapor interactions with $\mathrm{FeOOH}$ particle surfaces. Chem. Phys. Lett. 2013, 560, 1-9.

(35) Yalcin, S. E.; Legg, B. A.; Yeşilbaş, M.; Malvankar, N. S.; Boily, J.-F. Direct observation of anisotropic growth of water films on minerals driven by defects and surface tension. Sci. Adv. 2020, 6, eaaz9708.

(36) Cheng, W.; Hanna, K.; Boily, J.-F. Water Vapor Binding on Organic Matter-Coated Minerals. Environ. Sci. Technol. 2019, 53, 1252-1257.

(37) Boily, J.-F.; Fu, L.; Tuladhar, A.; Lu, Z.; Legg, B. A.; Wang, Z. M.; Wang, H. Hydrogen bonding and molecular orientations across thin water films on sapphire. J. Colloid Interface Sci. 2019, 555, 810817.

(38) Lindholm, J.; Boily, J.-F.; Holmboe, M. Deconvolution of Smectite Hydration Isotherms. ACS Earth Space Chem. 2019, 3, 2490-2498.

(39) Cygan, R. T.; Post, J. E.; Heaney, P. J.; Kubicki, J. D. Molecular models of birnessite and related hydrated layered minerals. Am. Miner. 2012, 97, 1505-1514.

(40) Lopano, C. L.; Heaney, P. J.; Bandstra, J. Z.; Post, J. E.; Brantley, S. L. Kinetic analysis of cation exchange in birnessite using time-resolved synchrotron X-ray diffraction. Geochim. Cosmochim. Acta 2011, 75, 3973-3981.

(41) Hochella, M. F.; Kasama, T.; Putnis, A.; Putnis, C. V.; Moore, J. $\mathrm{N}$. Environmentally important, poorly crystalline $\mathrm{Fe} / \mathrm{Mn}$ hydrous oxides: Ferrihydrite and a possibly new vernadite-like mineral from the Clark Fork River Superfund Complex. Am. Miner. 2005, 90, 718724.

(42) Kwon, K. D.; Refson, K.; Sposito, G. On the role of Mn(IV) vacancies in the photoreductive dissolution of hexagonal birnessite. Geochim. Cosmochim. Acta 2009, 73, 4142-4150.

(43) Ilton, E. S.; Post, J. E.; Heaney, P. J.; Ling, F. T.; Kerisit, S. N. XPS determination of Mn oxidation states in Mn (hydr)oxides. Appl. Surf. Sci. 2016, 366, 475-485.

(44) Ling, F. T.; Post, J. E.; Heaney, P. J.; Kubicki, J. D.; Santelli, C. M. Fourier-transform infrared spectroscopy (FTIR) analysis of triclinic and hexagonal birnessites. Spectrochim. Acta, Part A 2017, 178, 32-46.

(45) Zografi, G.; Kontny, M. J. Sorption of Water by Solids; Marcel Dekker: New York, 1995.

(46) Do, D. D. Adsorption Analysis: Equilibria and Kinetics; Imperial College Press: London, 1998; p 892.

(47) Hutson, N. D.; Yang, R. T. Theoretical basis for the DubininRadushkevitch (D-R) adsorption isotherm equation. Adsorption 1997, 3, 189-195.

(48) Do, D. D.; Do, H. D. A model for water adsorption in activated carbon. Carbon 2000, 38, 767-773.

(49) Jaumot, J.; Gargallo, R.; de Juan, A.; Tauler, R. A graphical userfriendly interface for MCR-ALS: a new tool for multivariate curve resolution in MATLAB. Chemom. Intell. Lab. Syst. 2005, 76, 101-110.

(50) Abraham, M. J.; Murtola, T.; Schulz, R.; Páll, S.; Smith, J. C.; Hess, B.; Lindahl, E. GROMACS: High performance molecular simulations through multi-level parallelism from laptops to supercomputers. SoftwareX 2015, 1-2, 19-25.

(51) Newton, A. G.; Kwon, K. D. Molecular simulations of hydrated phyllomanganates. Geochim. Cosmochim. Acta 2018, 235, 208-223.

(52) Berendsen, H. J. C.; Grigera, J. R.; Straatsma, T. P. The missing term in effective pair potentials. J. Phys. Chem. 1987, 91, 6269-6271. 
(53) Joung, I. S.; Cheatham, T. E., III Determination of alkali and halide monovalent ion parameters for use in explicitly solvated biomolecular simulations. J. Phys. Chem. B 2008, 112, 9020-9041.

(54) Smith, D. E. Molecular Computer Simulations of the Swelling Properties and Interlayer Structure of Cesium Montmorillonite. Langmuir 1998, 14, 5959-5967.

(55) Holmboe, M.; Bourg, I. C. Molecular Dynamics Simulations of Water and Sodium Diffusion in Smectite Interlayer Nanopores as a Function of Pore Size and Temperature. J. Phys. Chem. C 2014, 118, $1001-1013$.

(56) Sing, K. S. W.; Everett, D. H.; Haul, R. A. W.; Moscou, L.; Pierotti, R. A.; Rouquerol, J.; Siemieniewska, T. Reporting physisorption data for gas/solid systems with special reference to the determination of surface area and porosity (Recommendations 1984). Pure Appl. Chem. 1985, 57, 603-619.

(57) Yeşilbaş, M.; Holmboe, M.; Boily, J.-F. Cohesive Vibrational and Structural Depiction of Intercalated Water in Montmorillonite. ACS Earth Space Chem. 2018, 2, 38-47.

(58) Golden, D. C.; Chen, C. C.; Dixon, J. B. Transformation of birnessite to buserite, todorokite, and manganite under mild hydrothermal treatment. Clays Clay Miner. 1987, 35, 271-280.

(59) Potter, R. M.; Rossman, G. R. Tetravalent manganese oxides Identification, hydration, and structural relationships be infrared spectroscopy. Am. Miner. 1979, 64, 1199-1218.

(60) Lopano, C. L.; Heaney, P. J.; Post, J. E.; Hanson, J.; Komarneni, $\mathrm{S}$. Time-resolved structural analysis of $\mathrm{K}$ - and $\mathrm{Ba}$-exchange reactions with synthetic Na-birnessite using synchrotron X-ray diffraction. Am. Miner. 2007, 92, 380-387.

(61) Post, J. E.; Veblen, D. R. Crystal structure determinations of synthetic sodium, magnesium, and potassium birnessite using TEM and the Rietveld method. Am. Miner. 1990, 75, 477-489.

(62) Golden, D. C.; Dixon, J. B.; Chen, C. C. Ion Exchange, Thermal Transformations, and Oxidizing Properties of Birnessite. Clays Clay Miner. 1986, 34, 511-520.

(63) Wadsley, A. D. A hydrous manganese oxide with exchange properties. J. Am. Chem. Soc. 1950, 72, 1781-1784. 